\title{
The Size and Structure of the DNA Genome of Symbiont Xenosome Particles in the Ciliate Parauronema acutum
}

\author{
By A. T. SOLDO*, S. A. BRICKSON AND F. LARIN \\ Research Laboratories of the Veterans Administration Medical Center and the Department of \\ Biochemistry, University of Miami School of Medicine, Miami, Florida 33125, U.S.A.
}

(Received 30 June 1982; revised 4 August 1982)

\begin{abstract}
The size and structure of the DNA genome of xenosomes, bacterial endosymbionts of the marine hymenostome ciliate, Parauronema acutum 110-3, were investigated. Renaturation kinetic measurements, determined optically and by hydroxyapatite chromatography, suggested a genome size of $0.34 \times 10^{9}$ daltons. Sedimentation rate measurements of DNA gently released from the symbionts yielded molecules of comparable size. The analytical complexity, determined chemically, was $3.03 \times 10^{9}$ daltons. Consistent with these and other data is a model for the structure of the symbiont genome in which the DNA exists in the form of nine circularly permuted, double-stranded DNA molecules of unique sequence, each of molecular weight $0.34 \times 10^{9}$. It is suggested that xenosomes and certain symbionts found in ciliated protozoa may be extant forms of once free-living bacteria that have adapted to the intracellular environment.
\end{abstract}

\section{INTRODUCTION}

Self-reproducing bacterium-like symbionts, termed xenosomes, are found in the cytoplasm of the marine protozoon Parauronema acutum (Soldo et al., 1974). The symbionts, released from the host by gentle rupture, are capable of infecting homologous as well as heterologous strains of Parauronema spp. and at least one other ciliate of marine origin, Miamiensis avidus $\mathrm{Ma}$ (Soldo \& Brickson, 1978). The particles are also capable of killing other ciliate strains, especially those of the genus Uronema (Soldo \& Brickson, 1978). Bacterium-like symbionts appear to be widespread in nature, particularly among the protozoa; it has been suggested that they may represent a new class of organisms that have adapted to an intracellular existence (Soldo, 1974). To further characterize these organisms with respect to their nature and possible phylogenetic origins we have investigated the structure of the DNA genome of xenosomes, derived from $P$. acutum $110-3$, using renaturation rate kinetics, sedimentation rate data and electron microscopy.

\section{METHODS}

Culture methods. Xenosome-bearing Parauronema acutum were cultured axenically in $\mathrm{M}$ medium at $27^{\circ} \mathrm{C}$ in the dark. Mass cultures were prepared in $500 \mathrm{ml}$ batches in 4-litre Fernbach flasks and harvested in the early stationary phase of growth $(6 \mathrm{~d})$. Under these conditions protozoan populations ranged from 0.8 to $1.2 \times 10^{6} \mathrm{ml}^{-1}$ and yields were $3-4 \mathrm{ml}$ packed cells $1^{-1}$. The composition and preparation of $\mathrm{M}$ medium, maintenance of stock cultures, mass cultivation and harvesting procedures were described by Soldo \& Merlin (1972). Xenosome-free protozoa were obtained by treating xenosome-bearing animals with tetracycline $\left(100 \mu \mathrm{g} \mathrm{ml} \mathrm{m}^{-1}\right.$ for $\left.7 \mathrm{~d}\right)$ to selectively destroy the symbionts.

Isolation and purification of xenosomes. Xenosomes were isolated and purified from xenosome-bearing protozoa by (1) a modification of a procedure previously described for the isolation of mu and pi symbionts of Paramecium (Soldo \& Godoy, 1974), or (2) a procedure based on separation of the particles in discontinuous sucrose gradients. In the former method, instant sea water $\left(\rho=1.015 \mathrm{~g} \mathrm{~cm}^{-3}\right)$ (ISW), (Soldo \& Merlin, 1972) was used instead of migration salt solution (Soldo \& Godoy, 1974). The latter method, which has not been described previously, was as follows: Xenosome-bearing $P$. acutum from 1-41 of culture were collected in a de Laval continuous-flow centrifuge or by pelleting the animals at $1000 \mathrm{~g}$ for $5 \mathrm{~min}$ at $4{ }^{\circ} \mathrm{C}$ in $125 \mathrm{ml}$ capacity conical 
centrifuge bottles. After removal of the supernatant by aspiration, the pellets were suspended in 10 volumes of ISW and disrupted in a Waring blender. Completeness of cell breakage was verified by examination of samples of the homogenates in a phase microscope. The homogenate was then centrifuged at $1000 \mathrm{~g}$ for $5 \mathrm{~min}$ at $4{ }^{\circ} \mathrm{C}$. The cloudy supernatant was transferred by pipette to $50 \mathrm{ml}$ round-bottomed Nalgene tubes and centrifuged at $10000 \mathrm{~g}$ for $30 \mathrm{~min}$ at $4{ }^{\circ} \mathrm{C}$. After discarding the supernatant by decantation, the pellets were suspended with the aid of a vortex mixer in three successive $2 \mathrm{ml}$ portions of $0.5 \mathrm{M}$-sucrose prepared in ISW. The portions were combined in $12 \mathrm{ml}$ capacity centrifuge tubes and centrifuged at $500 \mathrm{~g}$ for $2 \mathrm{~min}$ to remove aggregated material. The supernatant (approximately $6 \mathrm{ml}$ ) was then transferred to a $\frac{5}{8}^{\prime \prime} \times 3^{\prime \prime}(16 \times 76 \mathrm{~mm})$ polyallomer tube. In successive portions, $2.5 \mathrm{ml}$ each of $1.5 \mathrm{M}$ - and $1.75 \mathrm{M}$-sucrose, and $1.0 \mathrm{ml} 2.0 \mathrm{M}$-sucrose were sub-layered with the aid of a glass funnel whose stem was positioned so that its tip (pulled in a glass flame to approximately $2 \mathrm{~mm}$ in diameter) rested at a point $1-2 \mathrm{~mm}$ above the bottom of the tube; the sucrose solutions were prepared in ISW. The tubes were then centrifuged at 30000 r.p.m. for $1.5 \mathrm{~h}$ at $4{ }^{\circ} \mathrm{C}$ using a Spinco rotor SW-36 in a model L-65 B ultracentrifuge. Xenosomes deposited at the interface between the $1.75 \mathrm{M}$ - and $2.0 \mathrm{M}$-sucrose layers, within the $2.0 \mathrm{M}$-sucrose layer and at the bottom of the tubes. Xenosomes at the interface and within the $2.0 \mathrm{M}$-sucrose layer were free of cellular and sub-cellular debris; those at the bottom of the tube contained refractile bodies. These bodies were shown previously to be excretory in nature and were composed mainly of guanine and hypoxanthine in insoluble form (Soldo et al., 1978). Their presence did not interfere with subsequent extraction and purification of DNA from xenosomes. Yields of xenosomes from 1 litre of culture ranged from 1.5 to $2.0 \times 10^{11}$.

Extraction and purification of DNA. DNA was extracted from freshly isolated xenosomes by the procedure of Marmur (1961). DNA from freshly harvested xenosome-bearing and xenosome-free protozoa was extracted as described by Soldo \& Godoy (1973). CsCl density gradient centrifugation was used for final purification of the DNA preparations. Yields of highly purified DNA from $2 \times 10^{11}$ xenosomes ranged from $0 \cdot 5$ to $1 \cdot 0 \mathrm{mg}$. Approximately 2-3 mg of highly purified whole-cell DNA was usually obtained from I litre of culture. We thank Dr Rudolf Werner of the University of Miami School of Medicine for the gift of bacteriophage $T_{4}$. The phage DNA was labelled with $\left[{ }^{3} \mathrm{H}\right]$ thymidine.

$\mathrm{CsCl}$ density gradient centrifugation. Analytical $\mathrm{CsCl}$ gradient centrifugation was carried out in a model $\mathrm{E}$ ultracentrifuge using samples containing 2-4 $\mathrm{g} \mathrm{DNA} \mathrm{ml}^{-1}$. Escherichia coli $\mathrm{K} 12$ DNA was included in each run as a reference marker $\left(\rho=1.710 \mathrm{~g} \mathrm{~cm}^{-3}\right)$. Preparative $\mathrm{CsCl}$ density gradient centrifugation was carried out using DNA samples containing 5-10 absorbancy units $(260 \mathrm{~nm})$ in $5.0 \mathrm{ml} \mathrm{CsCl}$ solution $\left(\rho=1.700 \mathrm{~g} \mathrm{~cm}^{-3}\right)$ at 55000 r.p.m. for $19 \mathrm{~h}$ at $20^{\circ} \mathrm{C}$ in a Spinco Vi 65 vertical rotor.

Thermal transition and renaturation. Thermal transition was followed by heating native DNA in standard saline citrate (SSC, containing $0.15 \mathrm{~mol} \mathrm{NaCl}$ and $0.015 \mathrm{~mol}$ trisodium citrate $1^{-1}$ ) at a rate of $0.5^{\circ} \mathrm{C} \mathrm{min}^{-1}$ during melting in a stoppered quartz cuvette $(1 \mathrm{~cm}$ light path) in a Gilford model 250 spectrophotometer using the automatic thermo-programmer. Denaturation and renaturation of the DNA samples were accomplished as previously described (Soldo \& Godoy, 1973). The reaction was followed at $260 \mathrm{~nm}$.

Determination of renaturation rate constants and kinetic complexity. Rate constants were calculated from secondorder renaturation rate plots (Wetmur \& Davidson, 1968). Alkaline sedimentation coefficients were estimated by the method of Studier (1965) using alkaline sucrose gradients calibrated by the procedures described by Martin \& Ames (1961). The kinetic complexity of the DNA samples was calculated from the renaturation rate constant and alkaline sedimentation coefficient using the formula of Wetmur \& Davidson (1968), as previously described (Soldo \& Godoy, 1973).

Kinetic complexity was also determined by hydroxyapatite chromatography (Britten \& Kohne, 1965), essentially as described by Soldo \& Godoy (1972) except that, during reassociation in $0 \cdot 12 \mathrm{M}-\mathrm{NaH}_{2} \mathrm{PO}_{4}$ at $60{ }^{\circ} \mathrm{C}$, samples were removed at shorter time intervals.

The genomic size of xenosome DNA was determined optically from second-order renaturation rate plots in SSC (Marmur, 1961) or $1 \mathrm{M}-\mathrm{NaCl}$, and by hydroxyapatite chromatography in $0 \cdot 12 \mathrm{M}-\mathrm{NaH}_{2} \mathrm{PO}_{4}, \mathrm{pH} 7 \cdot 0$ (Britten \& Kohne, 1965). For these determinations the DNA was sheared by sonication to a single-stranded size of about 100000 daltons. Bacteriophage $\mathrm{T}_{4}$ DNA, which has a $\mathrm{G}+\mathrm{C}$ content of $34 \mathrm{~mol} \%$, almost identical to that of xenosome DNA, was included in each run as a reference standard and obviated the need to correct for $\mathrm{G}+\mathrm{C}$ content (Wetmur \& Davidson, 1968).

Sedimentation measurements of genome size. Sedimentation patterns of ${ }^{14} \mathrm{C}$-labelled xenosome lysates were determined in $30 \mathrm{ml} 5-25 \%$ (w/v) linear sucrose gradients using the general procedures of Kavenhoff (1972). $\left[{ }^{3} \mathrm{H}\right]$ Thymidine-labelled bacteriophage $\mathrm{T}_{4}$ was included in each run as a marker. For these experiments it was necessary to label symbiont DNA. Attempts to introduce labelled thymine and its derivatives into symbiont DNA yielded purified preparations of low specific activity, i.e., a few hundred c.p.m. ( $\mu$ g DNA $)^{-1}$. $\left[{ }^{14} \mathrm{C}\right]$ Adenine, however, was an excellent precursor and it became possible to obtain symbiont DNA preparations with specific activities up to 35000 c.p.m. ( $\mu \mathrm{g}$ DNA $)^{-1}$. Xenosomes labelled with $\left[{ }^{1+} \mathrm{C}\right]$ adenine were isolated and purified. They were gently lysed in the lysis mixture described by Kavenhoff (1972) (except that sodium lauryl sulphate was used instead of Sarkosyl to effect lysis) and subjected to sucrose gradient centrifugation. Using the equation of Burgi \& 
Hershey (1963): $\left(s_{1} / s_{2}\right)=\left(M_{1} / M_{2}\right)^{0.35}$, where $s_{1}$ and $s_{2}$ are the sedimentation coefficients of two molecules of molecular weights $M_{1}$ and $M_{2}$, respectively. Values of $s$ and $M$ for $\mathrm{T}_{4}$ are $57 \mathrm{~S}$ and $0.13 \times 10^{9}$, respectively (Leighton \& Rubenstein, 1969).

Phase and electron microscopy. Aceto-orcein stained and unstained xenosome preparations were examined by phase microscopy as described previously (Soldo \& Brickson, 1978). Contour lengths of DNA released from xenosomes were measured by the protein monolayer techniques of Kleinschmidt et al. (1962).

Analytical procedures. DNA was determined by a modification of the diphenylamine procedure (Burton, 1956) and by a fluorescent method using ethidium bromide (Prasad et al., 1972). The orcinol procedure (Ogur \& Rosen, 1950) was used to measure RNA; carbohydrate was estimated by the anthrone procedure (Johanson, 1953). Protein was determined by the Lowry method. Base composition of DNA was determined by hydrolysis with $\mathrm{HClO}_{4}$ or formic acid followed by TLC. Quantitative measurements were made as described by Bendich (1957).

\section{RESULTS}

\section{DNA content of xenosomes}

Xenosomes were isolated and purified from $P$. acutum taken from both the mid-exponential $(3 \mathrm{~d})$ and early stationary $(6 \mathrm{~d})$ phases of growth, and analysed for DNA content. The DNA content of xenosomes isolated from the mid-exponential growth phase $( \pm$ S.D.) was significantly higher $(8 \pm 3 \mathrm{fg}$; six determinations of three preparations) than that of xenosomes taken from the early stationary phase $(5 \pm 1 \mathrm{fg}$; nine determinations of seven preparations). In a random population, cells are expected to contain from $n$ to $2 n$ the normal DNA complement in the form of replicating molecules, and in the early stationary growth phase it is expected that the genome consists of completed, non-replicating chromosomal DNA molecules. The analytical complexity of a genome containing $5 \mathrm{fg}$ DNA and consisting of a single unique DNA sequence would equal $3.03 \times 10^{9}$ daltons.

\section{Extraction of DNA}

Symbiont and whole-cell DNA were examined chemically and spectrophotometrically to determine the degree of purity of the preparations. Less than $1 \%$ protein was present; carbohydrate was not detected. Chromatograms of $\mathrm{HClO}_{4}$ and formic acid digests showed no evidence of a uracil spot. Absorbancy ratios $(230 / 260 \mathrm{~nm})$ averaged $0.42 ; 280 / 260 \mathrm{~nm}$ ratios averaged $0 \cdot 51$. These values are comparable to those reported for other DNAs (Marmur, 1961).

DNA from xenosome-free and xenosome-bearing protozoa, and from isolated and purified xenosomes, was subjected to preparative $\mathrm{CsCl}$ centrifugation (Fig. 1). A single DNA peak was observed with xenosome-free $P$. acutum (Fig. 1a), whereas a shoulder, representing DNA material of higher density than the main band, was seen in DNA of xenosome-bearing $P$. acutum (Fig. $1 b$ ). Figure $1(c)$ illustrates the $\mathrm{CsCl}$ profile of pooled fractions of the shoulder. Figure $1(d)$ represents DNA isolated from purified xenosomes. This DNA was indistinguishable from DNA derived from the recycling of the denser band of the gradient illustrated in Fig. 1 (c) (gradient not shown).

\section{DNA base composition}

Analytical $\mathrm{CsCl}$ gradient profiles of purified DNA from xenosome-bearing and xenosomefree $P$. acutum, and from isolated and purified xenosomes, showed that the density of the main band of $P$. acutum DNA was $1.680 \mathrm{~g} \mathrm{~cm}^{-3}$. DNA from xenosomes had a density of $1.694 \mathrm{~g} \mathrm{~cm}^{-3}$. A shoulder at density $1.694 \mathrm{~g} \mathrm{~cm}^{-3}$, observed in xenosome-bearing $P$. acutum DNA, was due to the presence of xenosome DNA. Mitochondrial DNA was not detected in either whole-cell xenosome-free or whole-cell xenosome-bearing $P$. acutum preparations.

The thermal transition of DNA isolated from xenosome-free $P$. acutum was fairly sharp and exhibited a uniform Gaussian distribution about the mean (Fig. 2a), while the thermal transition of DNA isolated from xenosome-bearing $P$. acutum exhibited a bimodal distribution about the mean (Fig. $2 b$ ). The thermal transition of DNA purified from xenosomes was very sharp; the Gaussian distribution about the mean was virtually unimodal and uniform (Fig. $2 c$ ). The values for the mid-point of thermal transition $\left(T_{m}\right)$ obtained from P. acutum (symbiont-free) 

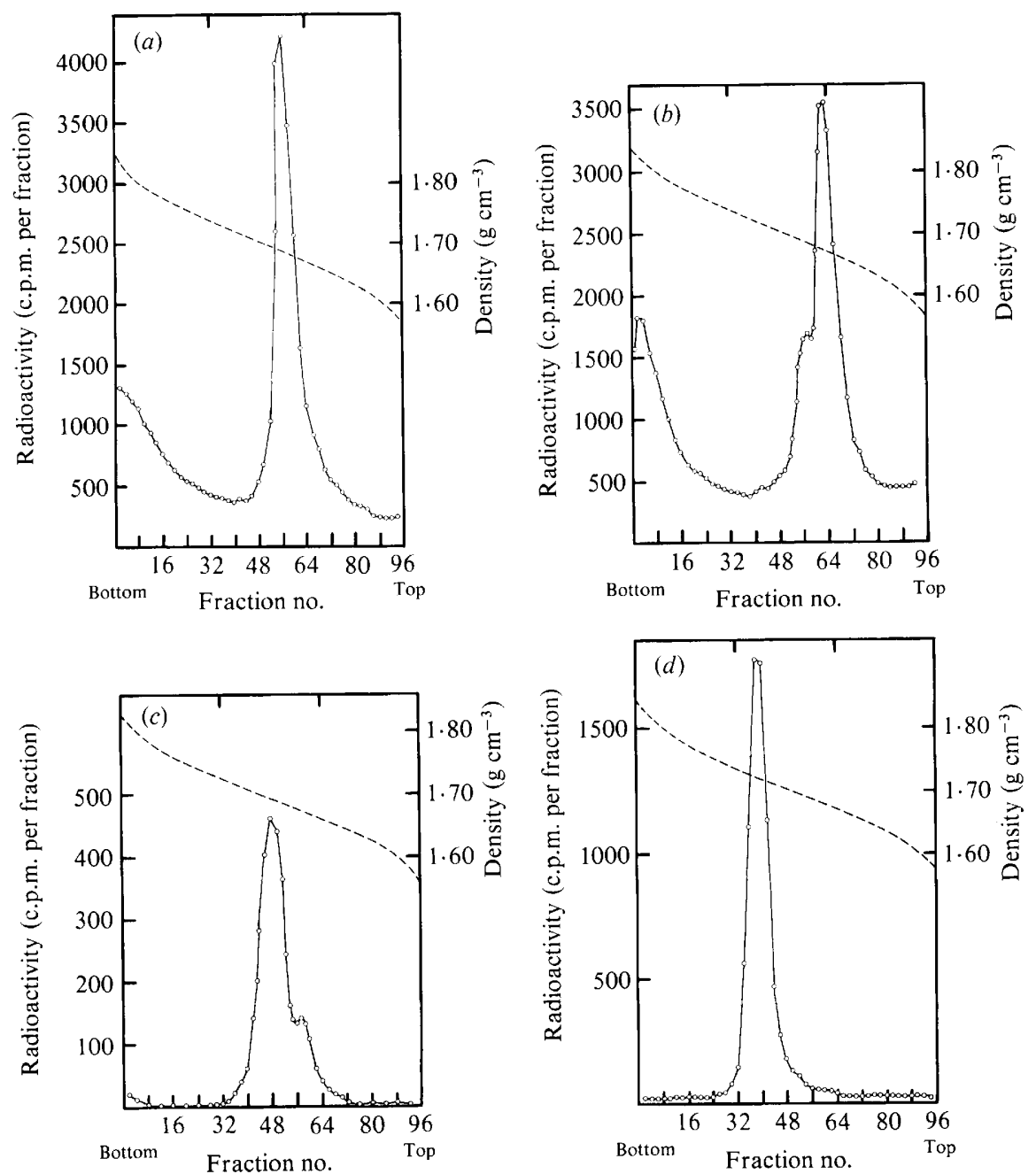

Fig. 1. Preparative $\mathrm{CsCl}$ gradient centrifugation. (a) Whole-cell P. acutum (xenosome-free) DNA; (b) whole-cell $P$. acutum (xenosome-bearing) DNA; (c) pooled fractions from shoulder (tubes 40-60) of gradient in $(b) ;(d)$ xenosome DNA. The DNA was labelled by culturing $P$. acutum (xenosome-bearing and xenosome-free) in the presence of $\left[{ }^{14} \mathrm{C}\right]$ adenine. - -, $\mathrm{CsCl}$ density.

Table 1. Base composition of whole-cell Parauronema acutum (symbiont-free) and purified xenosome DNA

Values represent the means of duplicate analyses of three preparations, \pm S.D.

\begin{tabular}{|c|c|c|}
\hline \multirow[b]{2}{*}{ Component } & \multicolumn{2}{|c|}{ Composition $(\mathrm{mol} \%)$} \\
\hline & . Whole-cell $P$. acutum & Xenosomes \\
\hline Guanine & $10 \cdot 3 \pm 0 \cdot 2$ & $17 \cdot 2 \pm 0 \cdot 4$ \\
\hline Cytosine & $9 \cdot 9 \pm 0 \cdot 2$ & $17 \cdot 0 \pm 1 \cdot 2$ \\
\hline Adenine & $39 \cdot 6 \pm 0 \cdot 3$ & $33 \cdot 2 \pm 0 \cdot 6$ \\
\hline Thymine & $40 \cdot 2 \pm 0 \cdot 3$ & $32 \cdot 6 \pm 1 \cdot 1$ \\
\hline $\mathrm{G}+\mathrm{C}$ (chromatography) & $20 \cdot 2$ & $34 \cdot 2$ \\
\hline $\mathrm{G}+\mathrm{C}\left(T_{m}\right)$ & $20 \cdot 0$ & $33 \cdot 9$ \\
\hline $\mathrm{G}+\mathrm{C}$ (buoyant density) & $20 \cdot 4$ & $34 \cdot 7$ \\
\hline
\end{tabular}



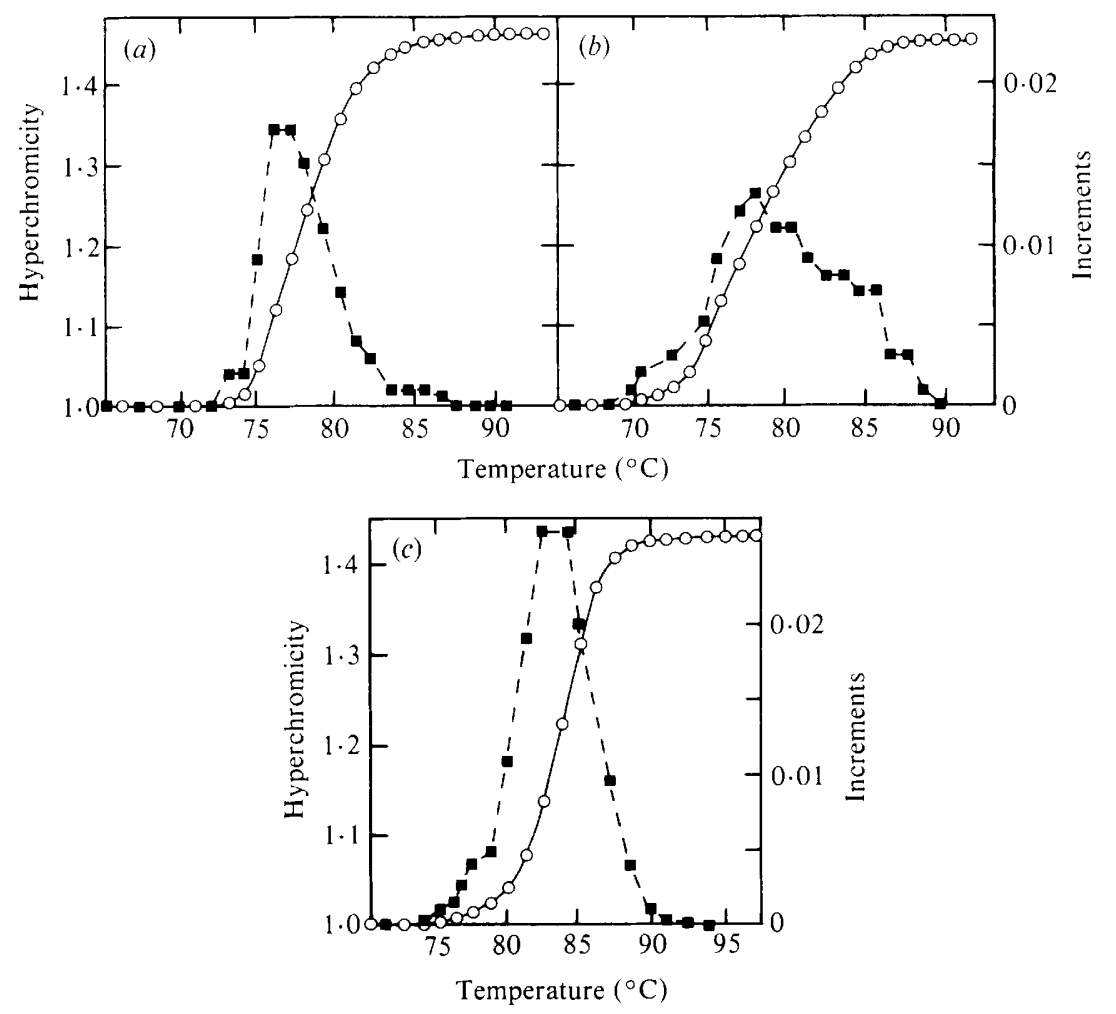

Fig. 2. Thermal transition in SSC. (a) Whole-cell $P$. acutum (xenosome-free) DNA; (b) whole-cell $P$. acutum (xenosome-bearing) DNA; (c) xenosome DNA. $O$, Hyperchromicity at $260 \mathrm{~nm}$; , increments ( $A_{260}$ units).

Table 2. Genome size from kinetic data

Values represent the means of six determinations of three preparations \pm S.D.

\begin{tabular}{|c|c|c|c|}
\hline \multirow[b]{2}{*}{ Method } & \multirow[b]{2}{*}{$\begin{array}{l}\text { Reassociation } \\
\text { solution }\end{array}$} & \multicolumn{2}{|c|}{$10^{-9} \times$ Molecular complexity (daltons } \\
\hline & & $\mathrm{T}_{4}$ & Xenosome \\
\hline Optical & $1 \mathrm{M}-\mathrm{NaCl}$ & $0 \cdot 13 \pm 0 \cdot 11$ & $0.35 \pm 0 \cdot 02$ \\
\hline Optical & $1 \times \mathrm{SSC}$ & $0 \cdot 13 \pm 0.12$ & $0 \cdot 32 \pm 0.04$ \\
\hline Hydroxyapatite chromatography & $0 \cdot 12 \mathrm{M}-\mathrm{NaH}, \mathrm{PO}_{4}$ & $0 \cdot 13 \pm 0 \cdot 10$ & $0 \cdot 36 \pm 0.03$ \\
\hline
\end{tabular}

and xenosome DNA were $77.5^{\circ} \mathrm{C}$ and $83.2{ }^{\circ} \mathrm{C}$, respectively. The base compositions of $P$. acutum and xenosome DNA calculated from these values are in excellent agreement with those derived from chromatographic and buoyant density data (Table 1). The results suggest that symbiont and protozoan DNA are native double-stranded molecules and are relatively homogeneous with respect to $\mathrm{G}+\mathrm{C}$ content. It is unlikely that they contain significant amounts of unusual sugars or bases.

\section{Genome size}

Renaturation rate plots followed theoretical second-order kinetics for about $30 \%$ of the reaction when determined by the optical method. For this reason the renaturation rate constants were estimated from the initial renaturation rates. On the other hand, renaturation using hydroxyapatite chromatography closely followed second-order kinetics. The results (Table 2) show that the kinetic complexity determined by three procedures was comparable. 


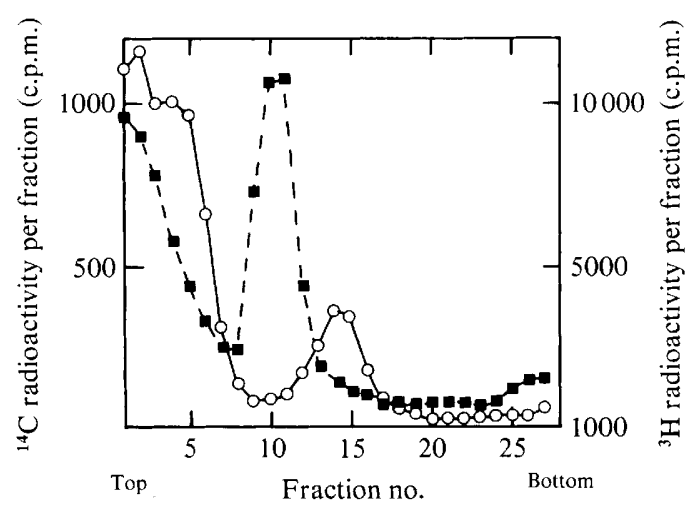

Fig. 3. Sedimentation pattern in a sucrose gradient of ${ }^{14} \mathrm{C}$-labelled DNA gently released from xenosomes (O), co-sedimented with ${ }^{3} \mathrm{H}$-labelled $\mathrm{T}_{4}$ bacteriophage DNA ( $\square$ ).

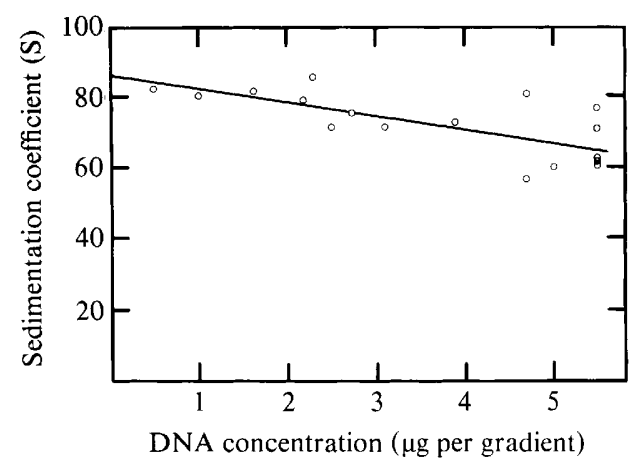

Fig. 4. Effect of DNA concentration on sedimentation coefficient.

Thus, the size of the symbiont DNA genome, determined kinetically, was about $0.34 \times 10^{9}$ daltons. On the other hand, the size of the genome determined chemically was $3.03 \times 10^{9}$ daltons. These results suggest that the DNA genome of the symbiont contains nine copies of a unique sequence. What then is the arrangement of these unique sequences within the symbiont genome? Two possibilities suggest themselves: (1) the unique sequences are arranged in tandem on a single DNA molecule of about $3 \times 10^{9}$ daltons, or (2) the unique sequences are arranged within the symbiont as a collection of nine individual DNA molecules each of about $0.34 \times 10^{9}$ daltons. Since it had been shown through sedimentation rate measurements that gentle lysates of bacteria produce large numbers of intact genomes (Kavenhoff, 1972), we applied this procedure to measure the size of the symbiont genome. In order to obtain more accurate measurements of the sedimentation coefficient(s), bacteriophage $\mathrm{T}_{4}$ labelled with $\left[{ }^{3} \mathrm{H}\right]$ thymidine was co-lysed with the symbionts in each run. Figure 3 illustrates a typical run. The rapidly sedimenting radioactive peak was identified as symbiont DNA by virtue of the fact that it was destroyed by the action of deoxyribonuclease. In a study of the size of the DNA genome of Bacillus subtilis, Kavenhoff (1972) found a strong dependence of the observed sedimentation rates on the speed of centrifugation. Our results with symbiont DNA showed only a negligible effect. The amount of DNA present significantly affected the $s$ value, however (Fig. 4). The mean value ( \pm S.D.) for the sedimentation coefficient for 17 symbiont preparations (corrected for concentration and speed of centrifugation) was $85.7 \pm 9 \mathrm{~S}$. From these data we calculate a molecular weight of 0.42 $\pm 0.13 \times 10^{9}$ for the symbiont genome, assuming a linearly-permuted molecule. In the case of phage DNA, Hershey et al. (1963) have calculated that $s$ (circular) $=s \times 1 \cdot 13$ (linear). If we assume a circularly-permuted molecule, the genome size of the symbiont DNA would be $0.30 \times$ $10^{9} \pm 0.09 \times 10^{9}$ daltons. 
Table 3. Size, $T_{m}$, kinetic and analytical complexities of the DNA of symbionts of ciliates

\begin{tabular}{|c|c|c|c|c|c|c|c|c|}
\hline \multirow[b]{2}{*}{ Protozoan host } & \multirow[b]{2}{*}{ Stock } & \multirow[b]{2}{*}{ Symbiont } & \multirow{2}{*}{$\begin{array}{c}\text { Size } \\
\text { (width } \times \\
\text { length, } \mu \mathrm{m} \text { ) }\end{array}$} & \multirow{2}{*}{$\begin{array}{c}T_{m} \\
\left({ }^{\circ} \mathrm{C}\right)\end{array}$} & \multicolumn{2}{|c|}{$\begin{array}{c}10^{-9} \times \text { Complexity } \\
\text { (daltons) }\end{array}$} & \multirow{2}{*}{$\begin{array}{l}\text { No. of } \\
\text { genomes }\end{array}$} & \multirow[b]{2}{*}{ Reference } \\
\hline & & & & & Kinetic & Analytic & & \\
\hline $\begin{array}{l}\text { Parauronema } \\
\text { acutum }\end{array}$ & $110-3$ & Xenosome & $0.3 \times 1.0$ & $33 \cdot 9$ & $0 \cdot 34$ & $3 \cdot 03$ & 9 & This study \\
\hline $\begin{array}{c}\text { Paramecium } \\
\text { octaurelia }\end{array}$ & 299 & Lambda & $0.65 \times 3.18$ & $26 \cdot 0$ & $0 \cdot 39$ & $7 \cdot 5$ & 19 & Soldo \& Godoy (1973) \\
\hline $\begin{array}{c}\text { Paramecium } \\
\text { octaurelia }\end{array}$ & 138 & $\mathrm{Mu}$ & $0.42 \times 1.63$ & $34 \cdot 2$ & 0.56 & $4 \cdot 45$ & 8 & Soldo \& Godoy (1974) \\
\hline $\begin{array}{r}\text { Paramecium } \\
\text { tetraurelia }\end{array}$ & 139 & $\mathrm{Pi}$ & $0.40 \times 1.52$ & $35 \cdot 6$ & $0 \cdot 59$ & $5 \cdot 05$ & $8-9$ & Soldo \& Godoy (1974) \\
\hline $\begin{array}{l}\text { Euplotes } \\
\quad \text { aediculatus }\end{array}$ & - & Omikron & $0.3 \times 5.0$ & $47 \cdot 5$ & $0 \cdot 5$ & $3 \cdot 5$ & 7 & $\begin{array}{l}\text { Schmidt \& Heckmann } \\
(1980)\end{array}$ \\
\hline
\end{tabular}

\section{DISCUSSION}

From the data presented in this paper, it is possible to exclude the model of the symbiont genome as a single molecule consisting of tandemly arranged DNA sequences. Clearly, the symbiont genome is composed of nine individual DNA molecules. Unfortunately, the data do not permit a clear-cut distinction between the linear or circular form. The size of the genome determined from kinetic data, $0.34 \times 10^{9}$ daltons, is intermediate between values of $0.30 \times 10^{9}$ (circular) and $0.42 \times 10^{9}$ (linear). It is possible that DNA released by gentle lysis of the symbionts sedimented as a collection of both circular and linear molecules and that the linear molecules arose through breakage during handling. An interpretation that the molecules are circularly permuted is supported in part by the fact that the value of $0.34 \times 10^{9}$ (from kinetic data) more closely agrees with the value of $0.3 \times 10^{9}$ (circular) obtained from sedimentation rate data. Attempts have been made to resolve this issue by examining, by electron microscopy, contour lengths of DNA molecules released from the symbionts by gentle lysis procedures, but they have been inconclusive. The largest intact molecule we have observed using these methods was linear and had a contour length of $160 \mathrm{~nm}$, corresponding to a molecular weight of $0.32 \times$ $10^{9}$. Nevertheless, a reasonable model for the structure of the symbiont genome is one in which the DNA exists in the form of nine circularly permuted, double-stranded molecules of unique sequence, each of molecular weight $0.34 \times 10^{9}$.

Small size and multicopy genomes appear to be the rule for bacterial endosymbionts of ciliated protozoa. Table 3 summarizes the data on the genome structure of symbionts of ciliates for which detailed information is available. Although the data must be considered preliminary, some comments appear justified. First, the symbionts vary significantly in size and $T_{m}$ values, suggesting a diversity of forms. With respect to size, values range from $0.3 \times 1.0 \mu \mathrm{m}$ (xenosomes) to $0.65 \times 3.18 \mu \mathrm{m}$ (lambda), corresponding to a difference in volume of almost 15fold. Despite this comparatively large difference, the genome sizes of the symbionts, measured kinetically, fall within a relatively narrow range $\left(0.34 \times 10^{9}\right.$ daltons for xenosomes to $0.59 \times 10^{9}$ daltons for pi). These sizes are comparable to those found among the rickettsias (Bak et al., 1969) and mycoplasmas (Bode \& Morowitz, 1967), and are the smallest known for bacteria. If we assume an average protein (mol. wt $=45000)$ is coded by a nucleotide sequence of about $8.2 \times$ $10^{5}$ daltons, the symbionts code for 400-700 proteins. By comparison, the free-living bacterium $E$. coli, which has a molecular complexity of $2.5 \times 10^{9}$ daltons (Cairns, 1963), codes for about 3000 proteins (Bode $\&$ Morowitz, 1967). Bacteriophage $\mathrm{T}_{4}$ contains sufficient DNA to code for about 160 proteins. Gibson et al. (1971) reported values of $3.3 \times 10^{9}$ and $3.4 \times 10^{9}$ daltons for the kinetic complexities of mu endosymbionts of Paramecium aurelia stocks 551 and 540, respectively. Because their paper did not contain details of the conditions of their experiments it is not possible to interpret their results meaningfully. A report on bipolar bodies, bacterial endosymbionts of the flagellate Crithidia oncopelti (Spencer \& Cross, 1975), suggests that the genome size of this endosymbiont, determined kinetically, was $2.7 \times 10^{9}$ daltons, equivalent in 
size to that of E. coli. Tuan \& Chang (1975) reported a very high value of $6.7 \times 10^{9}$ daltons for the kinetic complexity of the DNA of another bipolar body (Blastocrothidia culicis). In contrast, Schwemmler et al. (1975) found the kinetic complexity of leaf-hopper endosymbionts to range from $0.022 \times 10^{9}$ to $0.028 \times 10^{9}$ daltons, sufficient to code for only $25-30$ proteins.

We view the small genome size of symbionts of ciliated protozoa as the result of loss of genetic material through selective mutational events involving deletions of portions of once larger genomes of free-living bacteria. In effect, these symbionts may represent an heterogeneous group of extant forms of ancient bacteria. Similar views have already been presented (Preer $e t$ al., 1974; Soldo \& Godoy, 1973). Evolution of multicopy genomes is looked upon in a similar light, i.e., adaptation to an intracellular environment. Multiple copies of specific gene sequences may serve as a 'hedge' against loss of symbionts through mutation. In this respect it is of interest to note that free-living and parasitic bacteria have mainly single-copy genomes (Bak et al., 1970). The only exception reported thus far is that of Azotobacter vinelandii, which has a multicopy genome (Sadoff et al., 1979). Multicopy genomes are common among chloroplasts and mitochondria (Gillham, 1978).

\section{REFERENCES}

Bak, A. L., Black, F. T., Christiansen, C. \& FREUNDT, E. A. (1969). Genome size of mycoplasmal DNA. Nature, London 224, 1209-1210.

Bak, A. L., Christiansen, C. \& Stenderup, A. (1970). Bacterial genome sizes determined by DNA renaturation studies. Journal of General Microbiology 64, 377380

BENDICH, A. (1957). Methods for characterization of nucleic acids by base composition. Methods in Enzymology 3, 715723.

Bode, H. R. \& Morowitz, H. J. (1967). Size and structure of Mycoplasma hominis H39 chromosome. Journal of Molecular Biology 23, $191-199$.

Britten. R. J. \& Kohne, D. E. (1965). Nucleotide sequence repetition in DNA. Year Book, Carnegie Institute Washington 65, 78-125.

Burgi, E. \& Hershey, A. D. (1963). Sedimentation rate as a measure of molecular weight of DNA. Biopinisical Journal 3, 309-321.

BURTON, K. (1956). A study of the conditions and mechanism of the diphenylamine reaction for the colorimetric estimation of deoxyribonucleic acid. Biochemical Journal 62, 315-323.

CAIRns, J. (1963). The chromosome of Escherichia coli. Cold Spring Harbor Symposia on Quantitative Biology 28, $43-45$

Gibson, I., Chance, M. \& Williams, J. (1971). Extranuclear DNA and the endosymbionts of Paramecium aurelia. Nature, New Biology 234, 75-77.

Gillham, N. W. (1978). Organelle Heredity. New York: Raven Press.

Hershey, A. D., Burgi, E. \& Ingraham, L. (1963). Cohesion of DNA molecules isolated from phage Lambda. Proceedings of the National Academy of Sciences of the United States of America 49, 748-755.

JOHANSON, R. (1953). New specific reagent for ketosugars. Nature, London 172, 956-957.

KAVENHOFF, R. (1972). Characterization of the Bacillus suhtilis W23 genome by sedimentation. Journal of Molecular Biology 72, $801-806$.

Kleinschmid, A. K., LANG, D. \& JaCkerts, D. (1962). Preparation and length measurements of the total deoxyribonucleic acid content of $\mathrm{T}_{2}$ bacteriophages. Biochimica et biophysica acta 61, 857-864.
Leighton, S. B. \& Rubenstein, I. (1969). Calibration of molecular weight scales for DNA. Journal of Molecular Biology 46, 313-328.

Marmur, J. (1961). A procedure for the isolation of deoxyribonucleic acid from micro-organisms. Journal of Molecular Biology 3, 208-218.

Martin, R. G. \& Ames, B. N. (1961). A method for determining the sedimentation behavior of enzymes: application to protein mixtures. Journal of Biological Chemistry 236, 1372-1379.

Ogur, M. \& Rosen, G. (1950). The nucleic acids in plant tissues. 1. The extraction and estimation of deoxypentose nucleic acid and pentose nucleic acid. Archices of Biochemistry 2, 62-76.

Prasad, A. S., Dumouschelle, E., Koniuch, D. \& Oberlas, D. (1972). A simple fluorometric method for the determination of RNA and DNA in tissues. Journal of Laboratory and Clinical Medicine 80, 598 . 602.

Preer, J. R., Preer, L. B. \& Jurand, A. (1974). Kappa and other endosymbionts in Paramecium aurelia. Bacteriological Reviews 38, 113-163.

Sadoff, H., Schimel, B. \& Ellis, S. (1979). Characterization of Azotobacter vinelandii deoxyribonucleic acid and folded chromosomes. Journal of Bacteriology 138, 871-877.

SCHMiot, H. J. \& HeCKMANN, K. (1980). DNA of omikron. In Procedures of the International Colloquium on Endosymbiosis and Cell Research at Tübingen, pp. 108-112. Edited by W. Schwemmler \& H. Schenk. New York: de Gruyter.

Schwemmler, W., Hobom, G. \& Engel-Mitani, M. (1975). Isolation and characterization of leafhopper endosymbiont DNA. Cytobiologie 10, 249-259.

Soldo, A. T. (1974). Intracellular particles in Paramecium. In Paramecium. A Current Survey, pp. 377-442. Edited by W. J. Wagtendonk. Amsterdam, London, New York: Elsevier.

SOldO, A. T. \& BRICKSON, S. A. (1978). Observations on the ultrastructure, mode of infectivity and host range of xenosomes. Tissue and Cell 10, 609-618.

Soldo, A. T. \& Godoy, G. A. (1972). The kinetic complexity of Paramecium macronuclear deoxyribonucleic acid. Journal of Protozoology 19, 673-678. 
Soldo, A. T. \& Godoy, G. A. (1973). Molecular complexity of Paramecium symbiont Lambda deoxyribonucleic acid : evidence for the presence of a multicopy genome. Journal of Molecular Biology 73, 93-108.

Soldo, A. T. \& Godoy, G. A. (1974). The molecular complexity of $m u$ and $p i$ symbiont DNA of Paramecium aurelia. Nucleic Acids Research 1, 387-396.

Soldo, A. T. \& Merlin, E. J. (1972). The cultivation of symbiont-free marine ciliates in axenic medium. Journal of Protozoology 19, 519-524.

Soldo, A. T., Godoy, G. A. \& Brickson, S. A. (1974). Infectious particles in a marine ciliate. Nature, London 249, 284-286.

Soldo, A. T., Godoy, G. A. \& Larin, F. (1978).

Purine-excreting nature of refractile bodies in the marine ciliate Parauronema acutum. Journal of Protozoology 25, 416-418.

Spencer, R. \& Cross, G. A. M. (1975). Purification and properties of nucleic acids from an unusual cytoplasmic organelle in the flagellate Crithidia oncopelti. Biochimica et biophysica acta 390, 141-154.

Studier, F. W. (1965). Sedimentation studies of the size and shape of DNA. Journal of Molecular Biology 11, 373-390.

Tuan, R. S. \& Chang, K-P. (1975). Isolation of intracellular symbionts by immune lysis of flagellate protozoa and characterization of their DNA. Journal of Cell Biology 65, 309-323.

WetMur, J. G. \& Davidson, N. (1968). Kinetics of renaturation of DNA. Journal of Molecular Biology 31, 349-370. 